\title{
Use of rainfall patterns for effective management of rubber plantations in Eastern, North Central and Northern provinces of Sri Lanka
}

\author{
Wasana Wijesuriya*, D M A P Dissanayake*, H M L K Herath**, \\ S B Karunaratne**, P W Jeewanthi*, B R Kulasekera* and C S Gurusinghe**** \\ * Rubber Research Institute of Sri Lanka, Dartonfield, Aglawatta \\ ** Department of Agri Business Management, Wayamba University of Sri Lanka, \\ Makandura, Gonawila (NWP) \\ *** Faculty of Agriculture, University of Ruhuna, Mapalana, Kamburupitiya
}

Received: 04 March 2014

\begin{abstract}
This study employed daily rainfall values of 10 meteorological stations in Anuradhapura, Vavuniya, Ampara, Kilinochchi and Mullaitivu districts covering Agro Ecological Regions (AER), DL1b, DL2a, DL2b, DL1e, DLIf and DL3. The methodology involved descriptive statistical techniques to derive yearly and monthly variations and probability calculations to derive frequency of dry spells. Incidence of consecutive wet weeks was analysed using Markov chain analysis. Except for Ampara, the rest of the locations analysed in this study recorded an average annual rainfall less than the minimum rainfall requirement for rubber. The AERs in the Dry zone are vulnerable to droughts especially during March to August. The chance of having long dry spells is less than $20 \%$ in all the sites during October, November and December. If cultural operations are carried out according to a proper plan the repercussions of drought conditions can be minimized to a considerable extent. Accordingly, holing operation which requires a moist soil should be done during $17^{\text {th }}$ September to $30^{\text {th }}$ September followed by planting during $22^{\text {nd }}$ October to $04^{\text {th }}$ November to catch the maximum possible length of the wet season to assure maximum establishment success. First, second and third fertilizer applications in the first year of planting need to be done during $17^{\text {th }}$ to $31^{\text {st }}$ December, $26^{\text {th }}$ March to $8^{\text {th }}$ April and $24^{\text {th }}$ September to $7^{\text {th }}$ October respectively, to avoid heavy rains and dry spells. It is inevitable to prevent any departures from these stipulated dates since, uncertainty stands as all these dates have been computed using the probability theory. Hence proper cultural operations and moisture management practices, viz. irrigation, mulching and intercropping throughout the immature phase of rubber are of great importance to assure a healthy rubber plantation with minimum vacancies and accepted growth rates.
\end{abstract}

Key words: Markov chain analysis, rainfall analysis, rubber 
Wasana Wijesuriya et al.

\section{Introduction}

Rubber is a crop which has its all operations connected with the rainfall pattern. Hence, for timely and efficient operation of agronomic practices from planting through felling, one needs a thorough understanding of the prevailing rainfall pattern of the area. There have been several reports on the rainfall pattern in traditional rubber growing areas in the Wet Zone of Sri Lanka. Yet, such reports on nontraditional rubber growing areas are limited except for studies reported by Wijesuriya et al. (2005 \& 2010) focusing on Moneragala district. Through the recent development programmes under "Regaining Sri Lanka" such as, "Nagenahira Navodaya" and "Uthuru Wasanthaya", the rubber tree has been introduced to Eastern and Northern provinces which come under Intermediate and Dry Zone areas (Rodrigo et al., 2009). This move required more detailed analysis of rainfall in Northern and Eastern regions of Sri Lanka for better decision making to ensure sustainable rubber farming.

The ideal annual rainfall for rubber falls within the range of $1650 \mathrm{~mm}$ to 3000 $\mathrm{mm}$. The tree performance is severely affected by prolonged periods of dry weather when rainfall over consecutive six months period recorded less than $500 \mathrm{~mm}$, and also when rainfall is not uniformly distributed over the year (Yogaratnam, 2001). It has been observed that ideal rainfall conditions do not exist in non-traditional rubber growing areas in the drier areas
(Wijesuriya et al., 2010). Vulnerability of different agro-ecological regions for droughts has been identified by Chithranayana \& Punyawardene (2008). According to them, almost all regions of the island have a potential threat to droughts. However, the degree of vulnerability is more in the dry zone. Hence, rubber farming in drier areas is a challenge and need to handle carefully to avoid detrimental effects due to adverse environmental conditions.

The important information on rainfall with respect to agriculture are; the chance of rain, the start, end and length of the rainy season, amounts of rain that can be expected at specified probability levels and the risk of dry spells. Very simple to complicated statistical methods have been employed in analysis of rainfall. The probabilistic approach is very common and many studies have employed distribution free approaches. The pioneering work of Gabriel \& Neumann (1962) was the starting point for Markov chain models which are helpful in defining probable occurrence of dry and wet spells. This method was employed for the wet zone rubber growing areas by Wijesuriya $\&$ Herath (2001). This paper employs simple descriptive methods and Markov chain analysis for several rainfall stations in Northern, North Central and Eastern provinces of Sri Lanka which are located in the areas where rubber is introduced on experimental basis as onfarm participatory trials. Optimal dates for different agro-management practices in rubber farming have been suggested 
by Liyanage et al., (1984) for Raigama estate, Ingiriya located in the Low Country Wet Zone (LCWZ). Later, Wijesuriya \& Herath (2001) have reported an analysis of rainfall records in14 Meteorological stations in LCWZ, Low Country Intermediate and Mid Country Wet Zone. The main emphasis of this study is to devise an effective management plan, employing appropriate statistical analyses for cultural operations in Eastern, North Central and Northern provinces of Sri Lanka for sustainable rubber farming.

\section{Methodology}

\section{Selection of sites}

Selection of sites was done to represent the areas where rubber is recently introduced through various development programmes by Rubber Research Institute of Sri Lanka (RRISL) and
Rubber Development Department (RDD). Table 1 lists the stations considered against the agro-ecological regions (AER) and the duration of data availability. The geographical distribution of meteorological/rainfall stations is depicted in Fig. 1.

Organizing data and analysis of rainfall records

Daily records were summarized into annual, monthly and standard week bases for all the stations. Descriptive analyses including mean, minimum, maximum, standard deviation (SD) and coefficient of variation $(\mathrm{CV})$ were done on annual, monthly and standard week basis. For yearly and monthly totals, the $75 \%$ exceedance probability value was chosen by ranking the series from lowest to highest and selecting the $25^{\text {th }}$ percentile point of each series.

Table 1. Details of the meteorological stations selected for the study

\begin{tabular}{llll}
\hline District & Station & Agro-ecological zone & Data availability \\
\hline \multirow{2}{*}{ Anuradhapura } & Anuradhapura & DL 1b & $1980-2012$ \\
& Elayapattuwa & DL 1b & $2004-2012$ \\
& Medawachchiya & DL 1b & $1995-2012$ \\
Vavuniya & Pawatti Kulam & DL 1b & $1993-2012$ \\
& Vavuniya & DL 1b & $1980-2012$ \\
Ampara & Ampara Tank & DL 2b & $1980-2012$ \\
& Uhana & DL 2a & $2008-2011$ \\
Kilinochchi & Akkarayan Kulam & DL 1f & $1980-2012$ \\
& Iranamadu Tank & DL 3 & $1980-2012$ \\
Mullativu & Muthuiankadu Kulam & DL 1e & $1989-2012$ \\
\hline
\end{tabular}




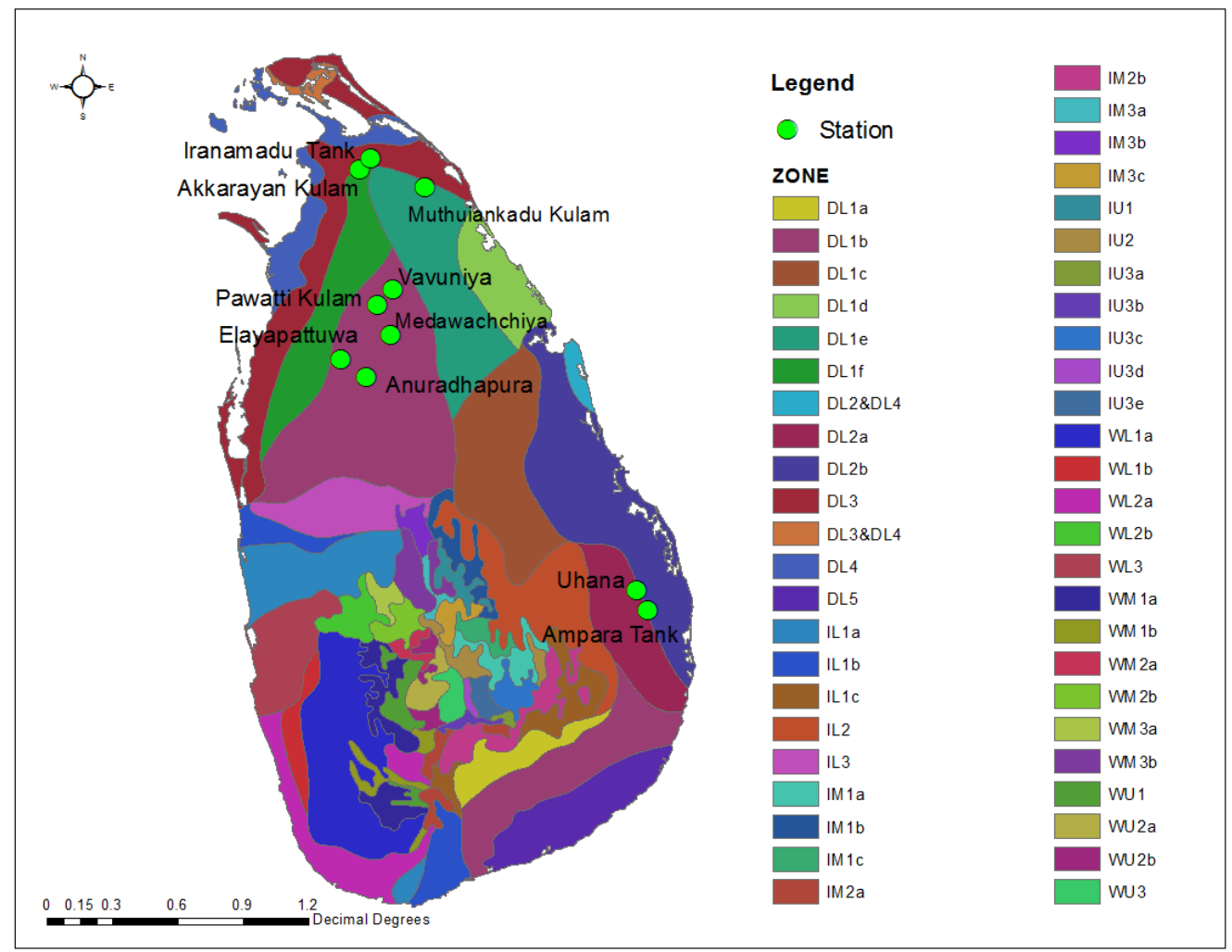

Fig.1. Geographical locations of selected meteorological stations

\section{Specific terms/criteria used in analysis}

Dry day - A threshold value of rainfall $<0.5 \mathrm{~mm}$ day $^{-1}$ was taken to define a dry day. This value was employed in detecting the onset of rains.

Onset of rains - Defining the onset of rains is difficult due to the wide variability of the specific nature of the rainfall pattern in Sri Lanka. A rainy day is defined as having a rainfall greater than or equal to $0.5 \mathrm{~mm}$. The start of rains is defined using three specific components as follows. i. The onset of rains is considered, after $1^{\text {st }}$ of March and $1^{\text {st }}$ of August for the $1^{\text {st }}$ rain spell and $2^{\text {nd }}$ rain spell, respectively.

ii. A potential start date will be the first occurrence of at least $30 \mathrm{~mm}$ of rain summed over three consecutive days with at least two rainy days.

iii. The potential start could be a false one if there is a seven-day dry spell within next twenty days after the potential start. 
Cease of rains - The end of rains is also difficult to decide due to the intermittent and patchy nature of rains in Sri Lanka. The definition of the cease of rains also depends on the particular application. The components that define the cease of rains are termed as follows.

i. The end date of rains is considered after $1^{\text {st }}$ July and $15^{\text {th }}$ January for the $1^{\text {st }}$ rain spell and $2^{\text {nd }}$ rain spell, respectively.

ii. The first 3-day dry spell is considered as a potential end of rains.

iii. This day is a false one if the total rainfall over next 20 days exceeds $100 \mathrm{~mm}$.

Wet week - A total of $20 \mathrm{~mm}$ or more is considered as a wet week since the average Potential Evapo-transpiration (PET) of the Dry zone is around 3mm/day (Punyawardene, 1998).

\section{Analysis of occurrence of dry spells}

For different months of the rainfall series, the occurrence of dry spells of different lengths, viz. 10, 15 and 20 days were counted. Subsequently, the occurrences were presented as probability of occurring dry spells of different lengths for different months.

\section{Analysis of occurrence of wet weeks}

The data set organized on standard week basis was employed in the analysis. For each year, using the total rainfall for the 52 standard weeks, the events were defined as 1 , if rainfall equals or exceeds $20 \mathrm{~mm}$ and 0 , otherwise. The probability values of receiving a wet week for each standard week were calculated accordingly.

\section{Markov chain analysis}

The first-order, two-state Markov probability matrix consist of four probabilities; probability of having a Wet week after a wet week (W/W), probability of having a dry week after a wet week (D/W), probability of having a wet week after a dry week (W/D) and probability of having a dry week after a dry week (D/D). This study was limited to finding the probability of receiving a wet week after a wet week (W/W) as it is expected to find the most suitable times for agro-management practices which requires sufficient amount of moisture retaining in the soil. The data set employed in analysis of occurrence of wet weeks was used to calculate the probability of having a wet week after a wet week (W/W).

\section{Results and Discussion Annual rainfall}

Five of the selected stations are found in agro-ecological region DL1b, which receives an overall rainfall of more than $900 \mathrm{~mm}$ annually with $75 \%$ probability (which means in 3 out 4 years, the annual rainfall exceeds $900 \mathrm{~mm}$ ). The analysis of $75 \%$ expected rainfall for these stations revealed that the highest value was recorded in Medawachchiya while the lowest was observed in Pawatti Kulam (Table 2). The station at Ampara tank belongs to DL2b with expected rainfall of $1100 \mathrm{~mm}$ at $75 \%$ probability. 
However, this location receives an annual rainfall more than $1417 \mathrm{~mm}$ at $75 \%$ probability. Akkrayan Kulam, Iranamadu tank and Muthuiankadu Kulam which belong to DL1f, DL3 and DL1e, respectively receive more than $800 \mathrm{~mm}$ with $75 \%$ probability. Yet, according to the analysis the station at Iranamadu tank receives more than 1128 $\mathrm{mm}$ with $75 \%$ probability. It was also noted that the coefficient of variation (CV\%) is lower in DL1b areas compared to the other stations indicating a lower variability in annual rainfall.

\section{Monthly rainfall}

Monthly variation in rainfall is depicted in Fig. 2 to Fig. 6 for meteorological stations in Anuradhapura, Vavuniya, Ampara, Kilinochchi and Mullaitivu districts, respectively. In Anuradhapura district, the bimodal pattern of rainfall exists with peaks that coincide in April and November. A slight departure was observed in Medawachchiya where the peak rainfall occurs in December. However, the pattern observed for $75 \%$ expected rainfall is similar for both stations (Fig. 2). It is also noted that 100 $\mathrm{mm}$ is exceeded with $75 \%$ probability in April, October and November for Anuradhapura, while in Medawachchiya, there is a chance to exceed $100 \mathrm{~mm}$ in December too.

Table 2. Descriptive statistics of annual rainfall in selected locations

\begin{tabular}{lllllll}
\hline Station & $\begin{array}{l}\text { Agro- } \\
\text { ecological } \\
\text { zone }\end{array}$ & $\begin{array}{l}\text { Average } \\
\text { annual } \\
\text { rainfall } \\
\text { (mm/year) }\end{array}$ & $\begin{array}{l}\mathbf{7 5 \%} \\
\text { expected } \\
\text { rainfall } \\
\text { (mm/year) }\end{array}$ & Min. & Max. & $\begin{array}{l}\text { Coefficient } \\
\text { of Variation } \\
\text { (CV\%) }\end{array}$ \\
\hline Anuradhapura & DL 1b & 1269 & 1097 & 849 & 1878 & 19.3 \\
Elayapattuwa & DL 1b & 1159 & $*$ & 838 & 1594 & $*$ \\
Medawachchiya & DL 1b & 1429 & 1201 & 812 & 2037 & 19.4 \\
Pawatti Kulam & DL 1b & 1064 & 820 & 675 & 1622 & 24.5 \\
Vavuniya & DL 1b & 1320 & 1167 & 812 & 2229 & 21.6 \\
Ampara Tank & DL 2b & 1764 & 1417 & 992 & 3273 & 26.7 \\
$\begin{array}{l}\text { Akkarayan } \\
\text { Kulam }\end{array}$ & DL 1f & 1216 & 995 & 547 & 1964 & 28.4 \\
Iranamadu Tank & DL 3 & 1247 & 1128 & 733 & 2242 & 27.7 \\
$\begin{array}{l}\text { Muthuiankadu } \\
\text { Kulam }\end{array}$ & DL 1e & 1316 & 962 & 511 & 2389 & 33.0 \\
\hline
\end{tabular}

* Not enough data to compute the statistics 
Monthly rainfall distributions in Vavuniya and Pawatti Kulam stations which belong to Vavuniya district exhibit similar patterns with peaks that coincide in April and November. Although Pawatti Kulam and Vavuniya stations are found in close proximity, Vavuniya receives more rains during October to December (Fig. 3).

The bimodal rainfall pattern does not exist in stations located in Ampara and Uhana. There is a chance to exceed 100 $\mathrm{mm}$ at $75 \%$ probability during October to January. December receives the highest rainfall (Fig. 4). Akkarayan Kulam and Iranamadu which belong to DL1f and DL3 regions, have their peaks in November and there is a chance to exceed $100 \mathrm{~mm}$ at $75 \%$ probability during October, November and December (Fig. 5). Muthuiankadu Kulam located in agro-ecological region DL1e also has its peak coinciding November but there is a chance to exceed $100 \mathrm{~mm}$ at $75 \%$ probability only in November and December.
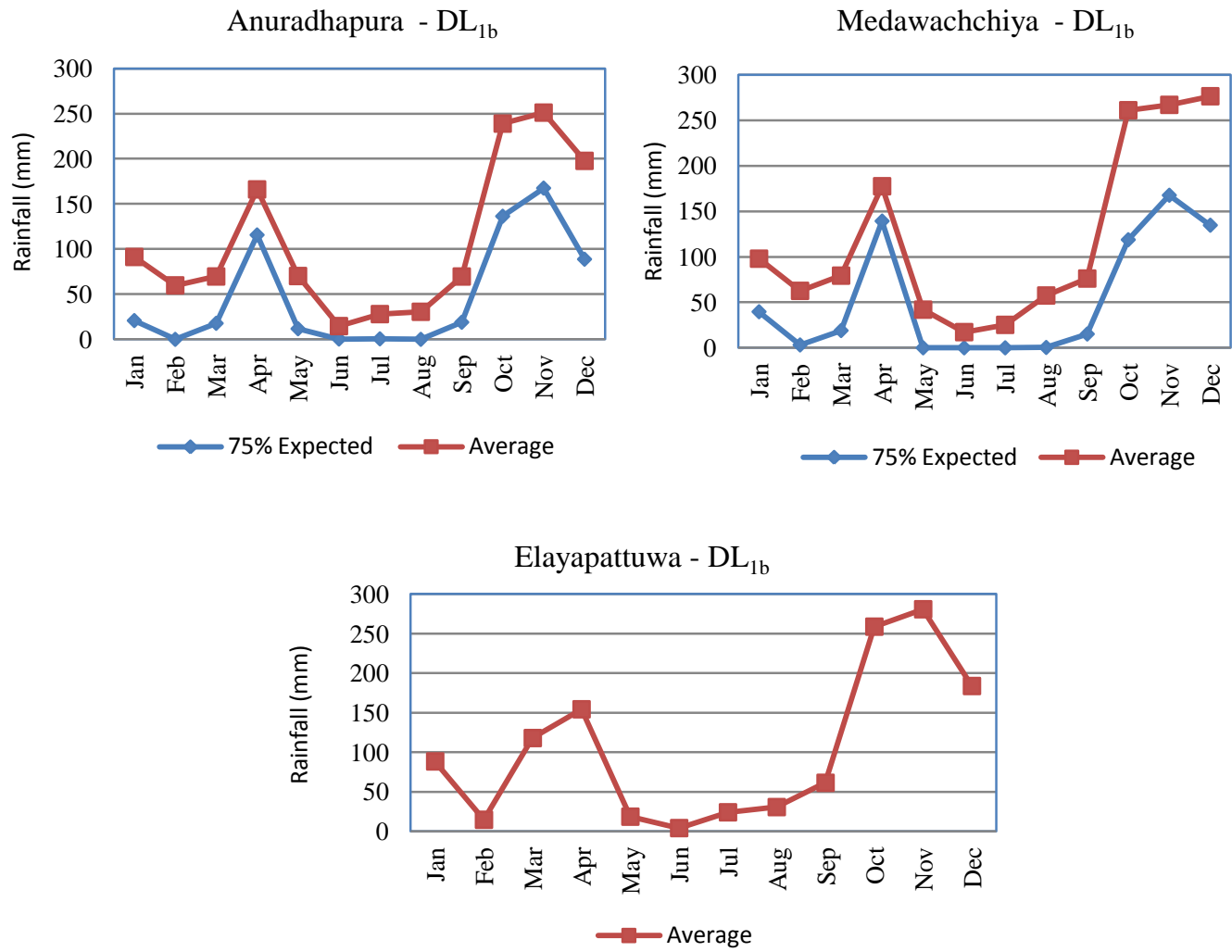

Fig. 2. Distribution of monthly average and $75 \%$ expected rainfall in stations located in Anuradhapura district 
Wasana Wijesuriya et al.
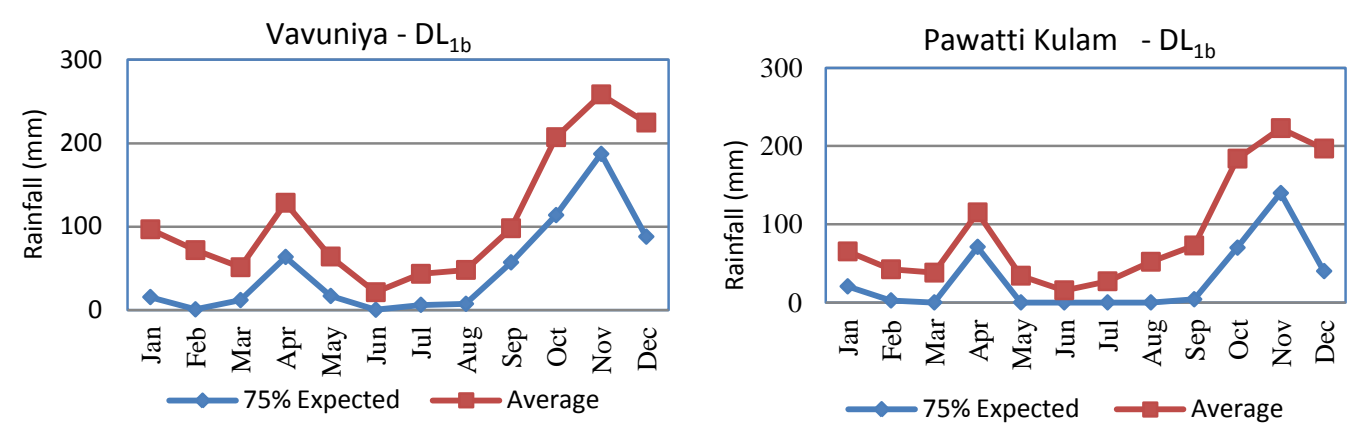

Fig. 3. Distribution of monthly average and $75 \%$ expected rainfall in stations located in Vavuniya district
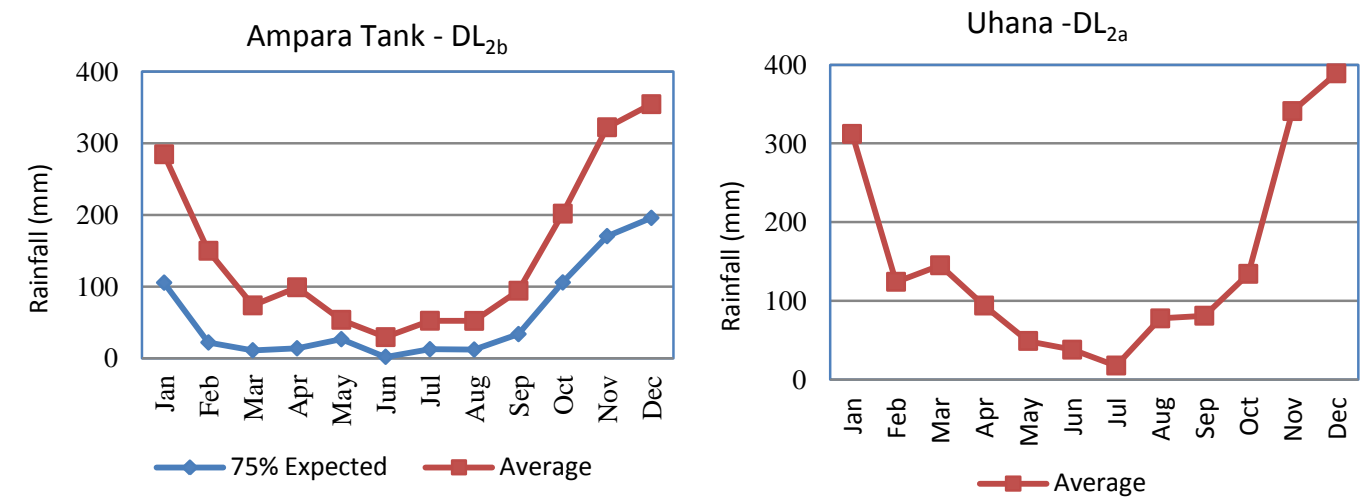

Fig. 4. Distribution of monthly average and $75 \%$ expected rainfall in stations located in Ampara district
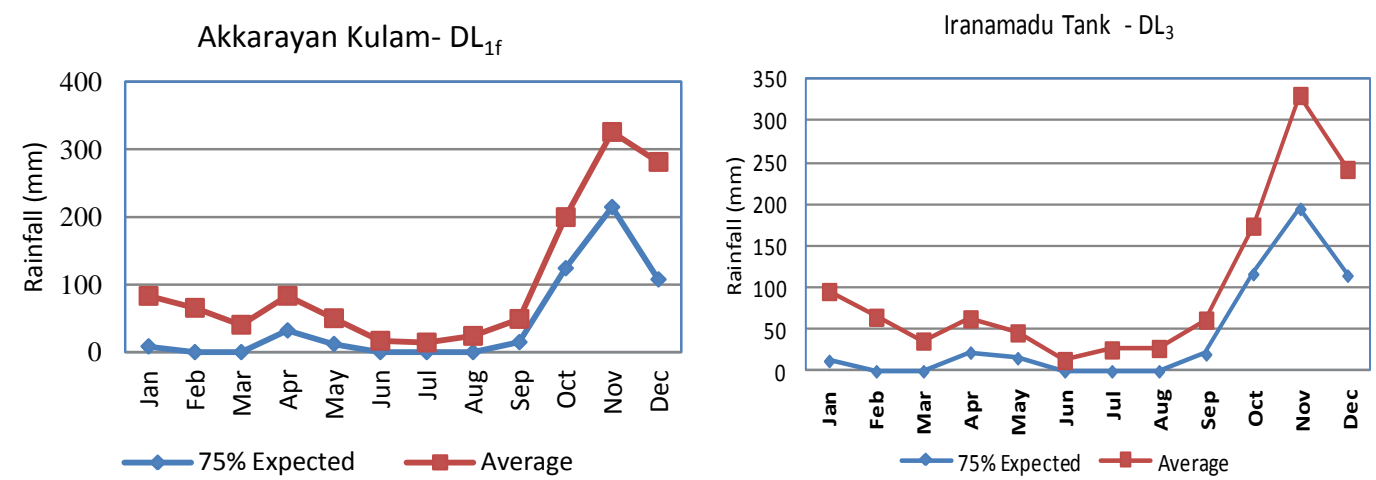

Fig. 5. Distribution of monthly average and $75 \%$ expected rainfall in stations located in Kilinochchi district 


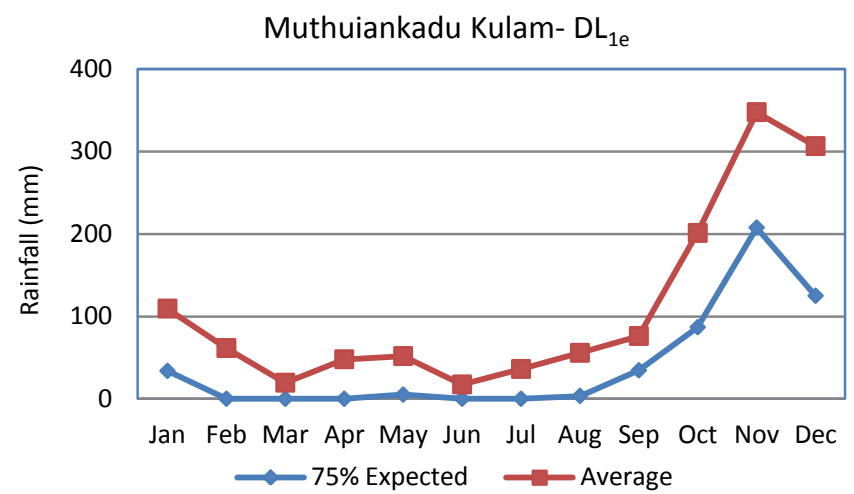

Fig. 6. Distribution of monthly average and $75 \%$ expected rainfall in stations located in Mullaitivu district

\section{Occurrence of dry spells}

The probability of occurrence of dry spells of different lengths in different months is depicted in Fig. 7 to Fig. 11. It is evident that probability of having long dry spells is less than $20 \%$ in all the sites during October, November and December. The chance of having dry spells more than 20 days is also less than 0.2 in April for stations located in agro-ecological region DL1b, in Ampara located in DL2b and in Iranamadu in DL3. There is only a

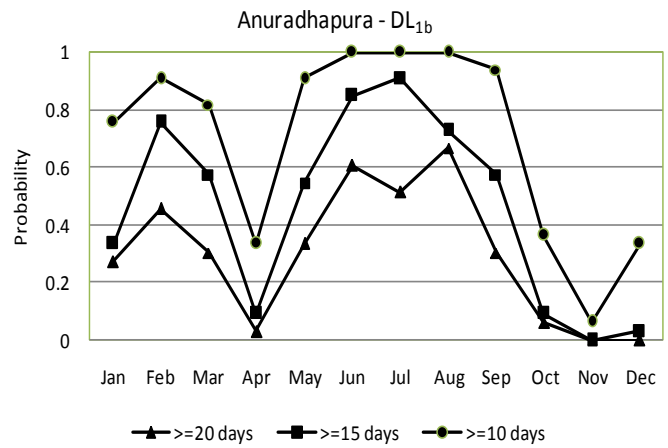

chance $20 \%$ to occur dry spells more than 20 days during January and September too, for Ampara.

The driest month is June in all the locations studied except for Anuradhapura where August has more chance to receive dry spells greater than 20 days. The chance exceeds $80 \%$ in Medawachchiya, Pawatti Kulam, Akkarayan Kulam, Iranamadu and Muthuiankadu Kulam (Fig. 7 to Fig. 11).

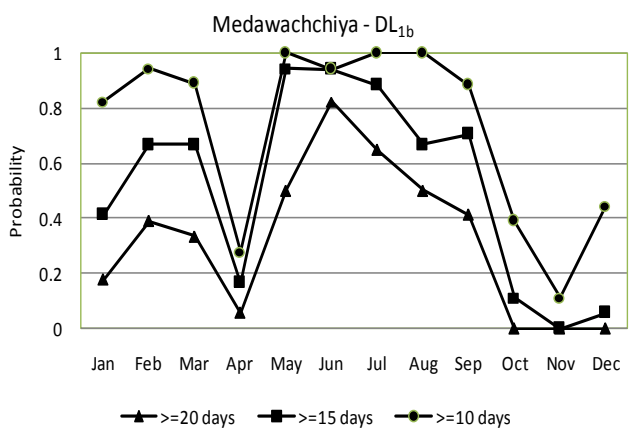

Fig. 7. Monthly distribution of frequency of dry spells of different lengths in Anuradhapura district 

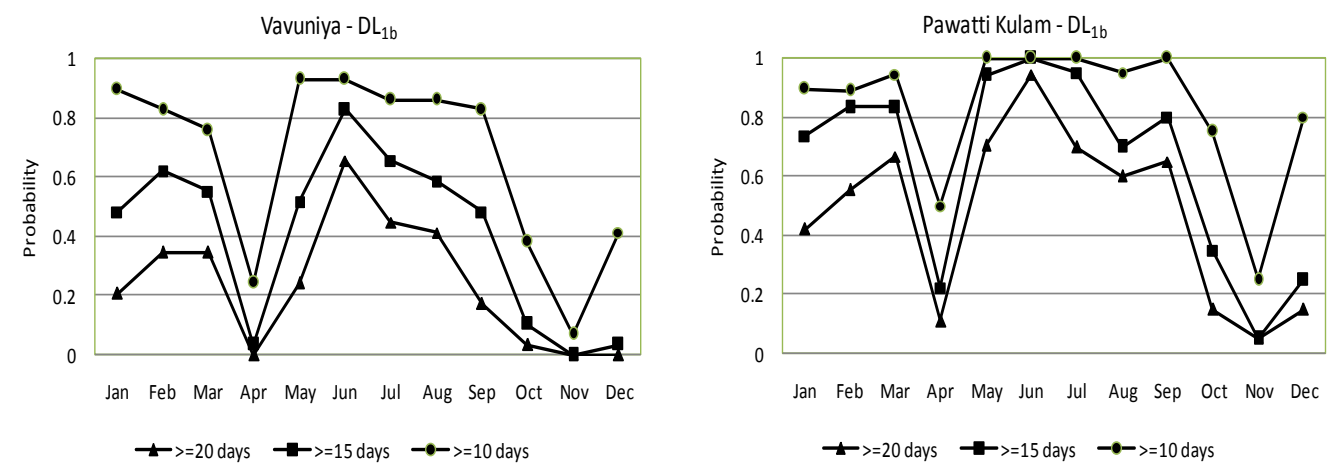

Fig. 8. Monthly distribution of frequency of dry spells of different lengths in Vavuniya district

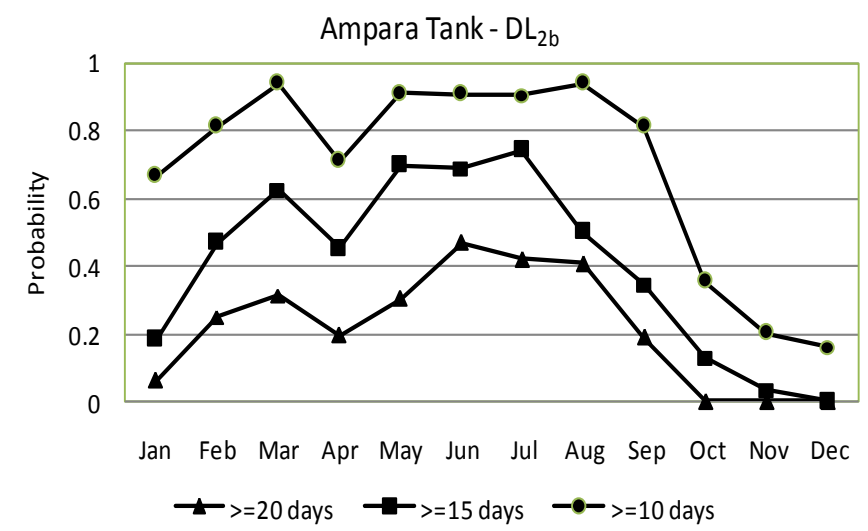

Fig. 9. Monthly distribution of frequency of dry spells of different lengths in Ampara district

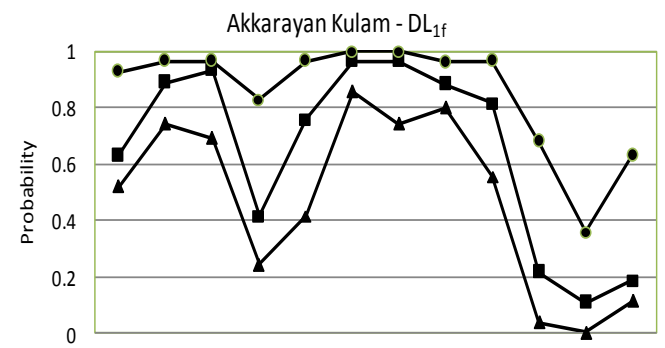

Jan Feb Mar Apr May Jun Jul Aug Sep Oct Nov Dec

$$
\longrightarrow>=20 \text { days } \rightarrow->=15 \text { days } \quad \rightarrow \bullet->=10 \text { days }
$$

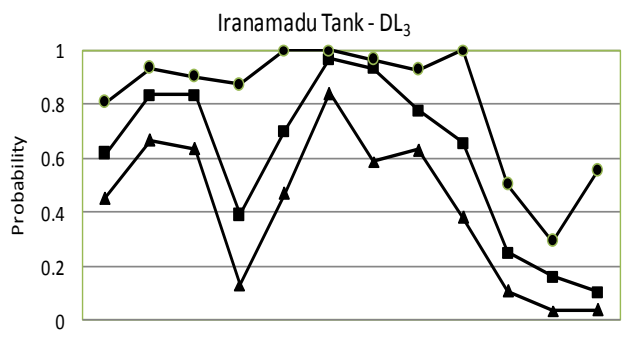

Jan Feb Mar Apr May Jun Jul Aug Sep Oct Nov Dec $\longrightarrow$ \>20 days $\rightarrow->=15$ days $\quad-\bullet->=10$ days

Fig.10. Monthly distribution of frequency of dry spells of different lengths in Kilinochchi district 


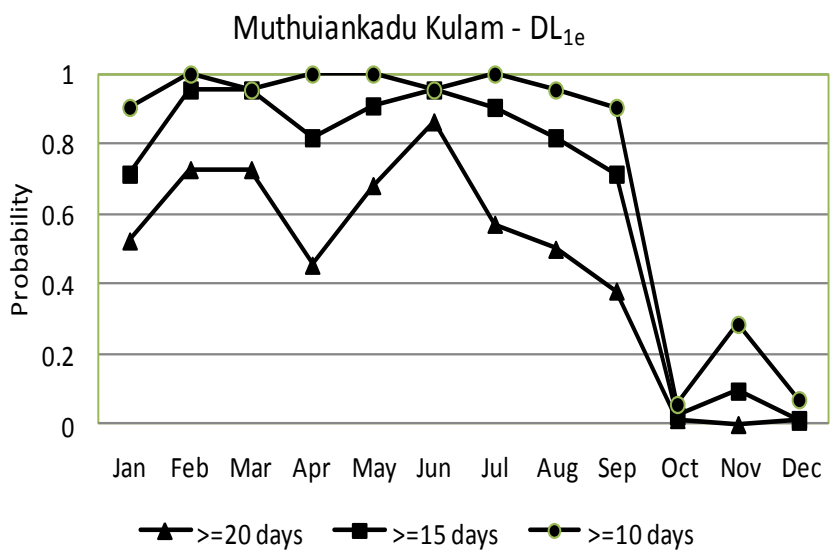

Fig. 11. Monthly distribution of frequency of dry spells of different lengths in Mullaitivu district

As stated by Chithranayana \& Punyawardene (2008) DL1f and DL3 regions exhibit mild drought during the Maha season with Moisture Availability Index (MAI) less than or equal to 0.33 in January and February. The areas that belong to DL1e are vulnerable to drought conditions during February. The agro-ecological regions DL2a and DL2b to which Uhana and Ampara areas belong to have no threat of drought during September to February. However, these areas are vulnerable to severe drought conditions during March to August (Fig. 4).

\section{Onset of rains}

Knowledge on onset of rains is a basic necessity in devising plans for agro- management practices. The dates of onset for $1^{\text {st }}$ and $2^{\text {nd }}$ rain spells for different locations are given in Table 3. Based on the criteria used for detection of onset and cease, the dates for onset and cease for the $1^{\text {st }}$ rain spell could be detected in the DL1b areas (Table 3). Further, the start of the $2^{\text {nd }}$ rain spell is about a week earlier than the areas in DL2b, DL1e, DL1f and DL3. There is $80 \%$ chance to cease the rain spell before $19^{\text {th }}$ January in 3 of the locations, $20^{\text {th }}$ January, $22^{\text {nd }}$ January and $6^{\text {th }}$ February in other locations (Table 3). The length of the $2^{\text {nd }}$ rain spell in Ampara is comparatively long compared to other locations. 
Wasana Wijesuriya et al.

Table 3. Dates of onset and cease of rains in selected locations in the dry zone

\begin{tabular}{|c|c|c|c|c|c|}
\hline \multirow[t]{2}{*}{ Station } & \multirow{2}{*}{$\begin{array}{l}\text { Agro- } \\
\text { ecological } \\
\text { zone }\end{array}$} & \multicolumn{2}{|c|}{$1^{\text {st }}$ rain spell } & \multicolumn{2}{|c|}{$2^{\text {nd }}$ rain spell } \\
\hline & & $\begin{array}{l}80 \% \\
\text { chance to } \\
\text { commence } \\
\text { before }\end{array}$ & $\begin{array}{l}80 \% \\
\text { chance to } \\
\text { cease } \\
\text { before }\end{array}$ & $\begin{array}{l}80 \% \text { chance to } \\
\text { commence } \\
\text { before }\end{array}$ & $\begin{array}{l}80 \% \text { chance } \\
\text { to cease } \\
\text { before }\end{array}$ \\
\hline Anuradhapura & DL $1 b$ & $2^{\text {nd }}$ April & $15^{\text {th }}$ July & $27^{\text {th }}$ October & $22^{\text {nd }}$ January \\
\hline Vavuniya & DL $1 b$ & $15^{\text {th }}$ April & $4^{\text {th }}$ July & $28^{\text {th }}$ October & $19^{\text {th }}$ January \\
\hline Ampara Tank & DL $2 b$ & - & - & $04^{\text {th }}$ November & $6^{\text {th }}$ February \\
\hline $\begin{array}{l}\text { Akkarayan } \\
\text { Kulam }\end{array}$ & DL $1 \mathrm{f}$ & - & - & $07^{\text {th }}$ November & $20^{\text {th }}$ January \\
\hline Iranamadu Tank & DL3 & - & - & $03^{\text {rd }}$ November & $19^{\text {th }}$ January \\
\hline $\begin{array}{l}\text { Muthuiankadu } \\
\text { Kulam }\end{array}$ & DL $1 \mathrm{e}$ & - & - & $03^{\text {rd }}$ November & $19^{\text {th }}$ January \\
\hline
\end{tabular}

Chance of receiving consecutive wet weeks

The probability of receiving a wet week after a wet week (W/W) can be used in finding suitable time periods for agromanagement practices in rubber planting. The results obtained by the Markov chain analysis are depicted in Figs. 12 to Fig. 15. A comparison of probabilities of receiving W/W $(>=20 \mathrm{~mm})$ is depicted in Fig. 16. It is apparent that in Anuradhapura and Medawachchiya (DL1b) there exist a considerably long wet period during the standard weeks 13-17, which can be effectively used for agro-management practices although it is not strong compared to the year-end wet period. However, in Vavuniya and Pawatti Kulam although belong to DL1b, this period is limited for 3 weeks (15-17) and 2 weeks (16 and 17), respectively. There appeared a chance of $50 \%$ or more to have consecutive 2 wet weeks for a fairly long period in DL1b areas except Pawatti Kulam, which has only 3 weeks which receive consecutive 2 wet weeks during the latter part of the year (Fig. 16).

As depicted in Fig. 14, the probabilities of receiving W/W $(20 \mathrm{~mm})$ in Muthuiankadu Kulam which is more towards the East coast of Sri Lanka (DL1e) during the latter part of the year is high compared to Iranamadu (DL3) and Akkarayan Kulam (DL1f). This phenomenon is also clearly depicted in Fig. 16.

The situation in Ampara is somewhat different as depicted in Fig. 15. The probabilities of receiving W/W $(20 \mathrm{~mm})$ is $0.3-0.49$ during 39 to $42,>=0.5$ from standard weeks 43 to 52 and extends to the $1^{\text {st }}$ week in the next year and followed by 4 more weeks with a probability between $0.3-0.49$ (Fig. 16). 


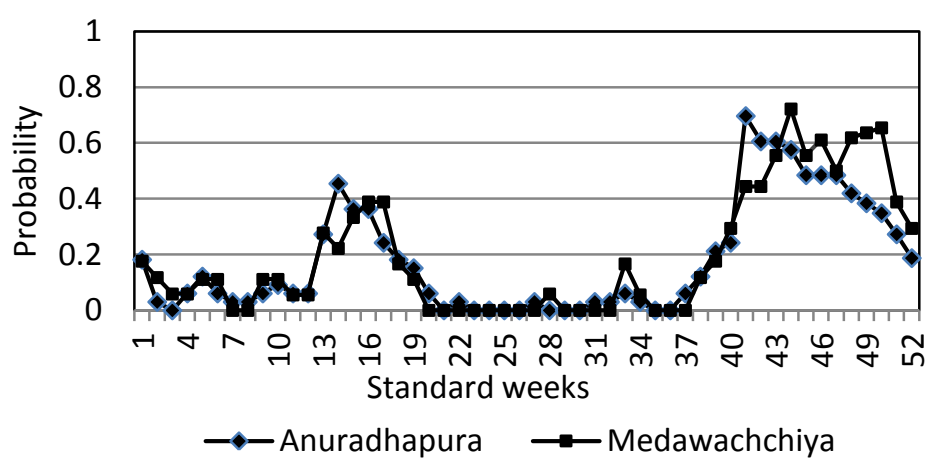

Fig. 12. The probabilities associated with occurring a wet week after a wet week in Anuradhapura and Medawachchiya in Anuradhapura district (DL1b)

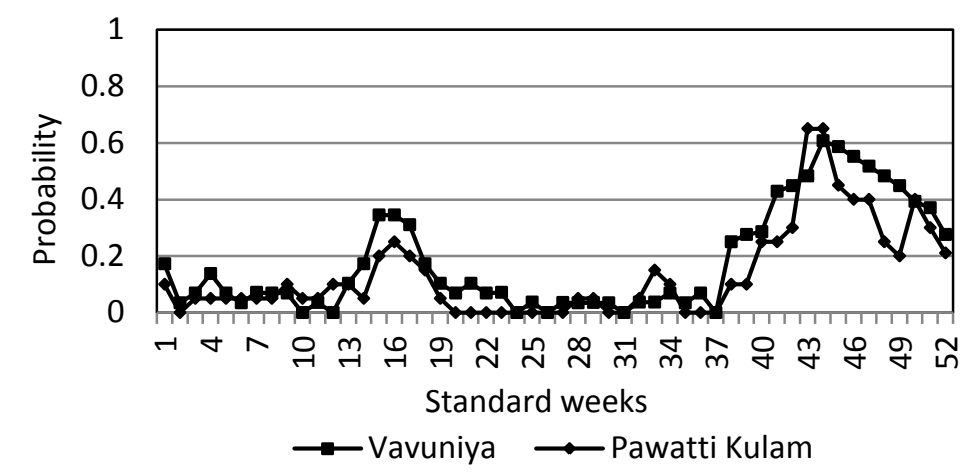

Fig. 13. The probabilities associated with occurring a wet week after a wet week in Vavuniya and Pawatti Kulam (DL1b) in Vavuniya district

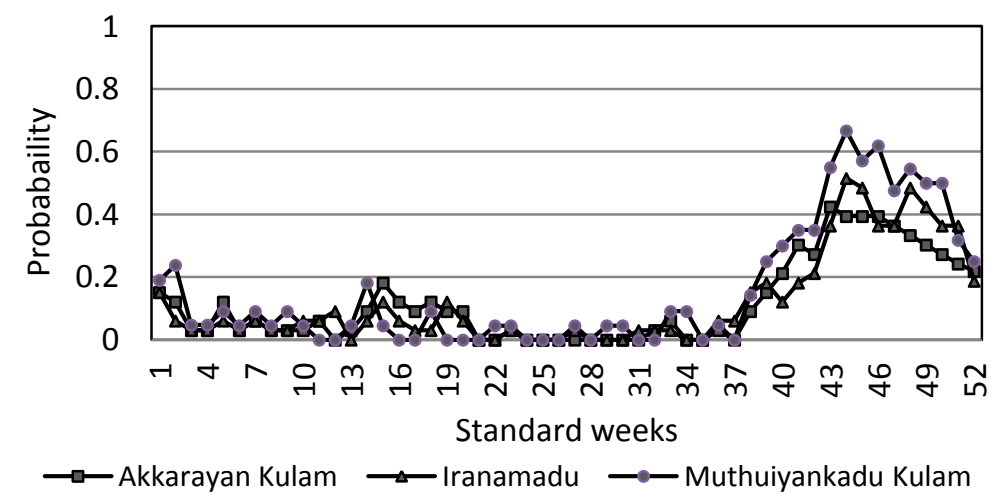

Fig. 14. The probabilities associated with occurring a wet week after a wet week in Akkarayan Kulam (DL1f), Iranamadu (DL3) and Muthuiankadu Kulam (DL1e) in Kilinochchi and Mullaitivu districts 


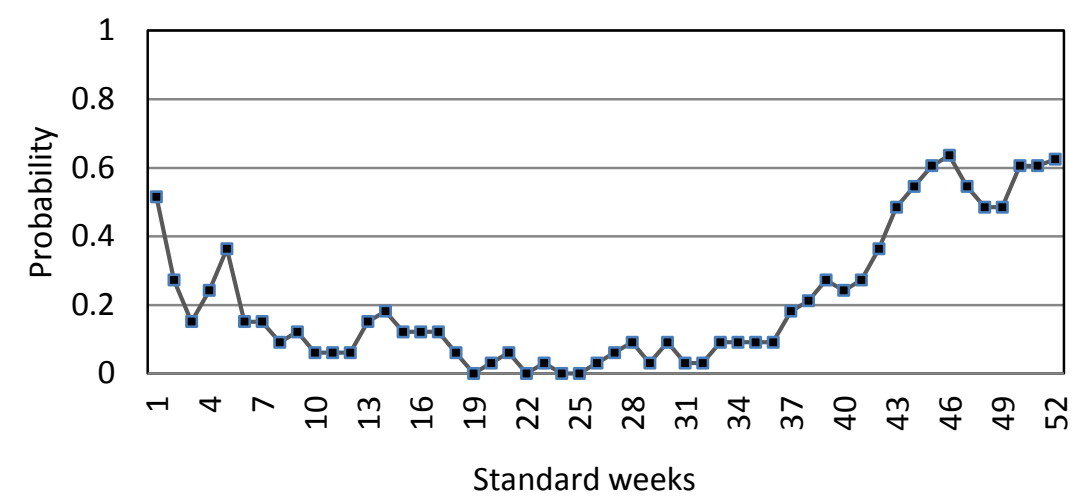

Fig. 15. The probabilities associated with occurring a wet week after a wet week in Ampara (DL2b)

\section{Optimal dates for major agro- management practices of rubber planting}

The major agricultural operations of rubber farming considered in this study are holing, planting and fertilizer application. Planting is the most important operation in rubber cultivation. Hence, it is important to time this operation properly to attain maximum possible establishment success. There is no option other than planting rubber in October/November period with the onset of $2^{\text {nd }}$ rain spell in the locations considered in this study.

In areas which belong to agroecological region, DL1there is $80 \%$ of chance to begin the $2^{\text {nd }}$ rain spell before the end of October. The average onset date for Anuradhapura is $10^{\text {th }}$ October and for Vavuniya it is $11^{\text {th }}$ October. The average end date for both these locations is $19^{\text {th }}$ January and the length of the rain spell is 101 days. During the months, October to December the risk of having long dry spells (>20 days) is very low (Fig. 7 \& Fig. 8). Hence, planting can be commenced after $22^{\text {nd }}$ October ( $43^{\text {rd }}$ standard week) in these areas. There will be minimal risk of receiving dry spells until the end of the year for these areas. However, it is important to complete planting during $43^{\text {rd }}$ and $44^{\text {th }}$ weeks $\left(22^{\text {nd }}\right.$ October to $04^{\text {th }}$ November) because the $1^{\text {st }}$ fertilizer application need to be done when there is sufficient moisture in the soil.

Holing is usually carried out in the Wet zone areas during late March when scattered showers are set in. A moist soil is generally required for this operation and holing should be done about 1 to $1 \frac{1}{2}$ months before planting. Therefore, to match with the planting dates holing can be done during $38^{\text {th }}$ or $39^{\text {th }}$ standard weeks $\left(17^{\text {th }}\right.$ September to $30^{\text {th }}$ September). 


\begin{tabular}{|c|c|c|c|c|c|c|c|c|}
\hline \multirow{2}{*}{$\begin{array}{l}\text { Std. week } \\
\text { No. }\end{array}$} & \multicolumn{8}{|c|}{ Location } \\
\hline & 1 & 2 & 3 & 4 & 5 & 6 & 7 & 8 \\
\hline \multicolumn{9}{|l|}{1} \\
\hline \multicolumn{9}{|c|}{2} \\
\hline \multicolumn{9}{|l|}{3} \\
\hline \multicolumn{9}{|c|}{4} \\
\hline \multicolumn{9}{|l|}{5} \\
\hline \multicolumn{9}{|c|}{6} \\
\hline \multicolumn{9}{|l|}{7} \\
\hline \multicolumn{9}{|c|}{8} \\
\hline \multicolumn{9}{|l|}{9} \\
\hline \multicolumn{9}{|l|}{10} \\
\hline \multicolumn{9}{|l|}{11} \\
\hline \multicolumn{9}{|l|}{12} \\
\hline \multicolumn{9}{|l|}{13} \\
\hline \multicolumn{9}{|l|}{14} \\
\hline \multicolumn{9}{|l|}{15} \\
\hline \multicolumn{9}{|l|}{16} \\
\hline \multicolumn{9}{|l|}{17} \\
\hline \multicolumn{9}{|l|}{18} \\
\hline \\
\hline & & & & & & & & \\
\hline \multicolumn{9}{|l|}{36} \\
\hline \multicolumn{9}{|l|}{37} \\
\hline \multicolumn{9}{|l|}{38} \\
\hline \multicolumn{9}{|l|}{39} \\
\hline 40 & & & & & & & & \\
\hline 41 & & & & & & & & \\
\hline 42 & & & & & & & & \\
\hline 43 & & & & & & & & \\
\hline 44 & & & & & & & & \\
\hline 45 & & & & & & & & \\
\hline 46 & & & & & & & & \\
\hline 47 & & & & & & & & \\
\hline 48 & & & & & & & & \\
\hline 49 & & & & & & & & \\
\hline 50 & & & & & & & & \\
\hline 51 & & & & & & & & \\
\hline 52 & & & & & & & & \\
\hline
\end{tabular}

\begin{tabular}{|l|l|}
\hline No. & Station \\
\hline 1 & Anuradhapura (DL1b) \\
\hline 2 & Medawachchiya (DL1b) \\
\hline 3 & Vavuniya (DL1b) \\
\hline 4 & Pawatti Kulam (DL1b) \\
\hline 5 & Ampara (DL2b) \\
\hline 6 & Akkarayan Kulam (DL1f) \\
\hline 7 & Iranamadu (DL3) \\
\hline 8 & Muthuiankadu Kulam (DL1e) \\
\hline
\end{tabular}

Probability (W/W) $->20 \mathrm{~mm} /$ week
$\begin{aligned} & 0.3 \text { to } 0.49 \\ & >=0.5\end{aligned}$

Fig. 16. Periods associated with different probabilities for receiving wet after a wet week $(>20 \mathrm{~mm}$ ) in different locations 
Wasana Wijesuriya et al.

As stated above, the $1^{\text {st }}$ fertilizer application is due 2 months after planting coincides with the $51^{\text {st }}$ or $52^{\text {nd }}$ week. This period is usually without heavy showers and has sufficient moisture retained in the soil from the $2^{\text {nd }}$ rain spell which is more effective in these areas. For the $2^{\text {nd }}$ application of fertilizer, $13^{\text {th }}$ or $14^{\text {th }}$ weeks are suitable ( $26^{\text {th }}$ March to $8^{\text {th }}$ April) and the next application should coincide with $39^{\text {th }}$ or $40^{\text {th }}$ weeks $\left(24^{\text {th }}\right.$ September to $7^{\text {th }}$ October) before heavy rains begin to occur in the $2^{\text {nd }}$ rain spell.

The average onset date of the $2^{\text {nd }}$ rain spell in Ampara area which belongs to DL2b is $14^{\text {th }}$ October and the average end date is $25^{\text {th }}$ January and has an average length of 103 days which is quite similar to DL1b areas. Holing, planting and fertilizer applications can be done in DL2b areas according to the dates suggested for DL1b areas. However, it should be noted that the risk of experiencing a 20 days dry spell is more (20\%) compared to DL1b areas during April and hence more thought should be given to moisture conservation measures.

According to Fig. 16, a similar agromanagement plan can be employed in rubber planting in the areas that belong to DL1f, DL1e and DL3. It is further supported by Fig. 11. Yet, the probability of receiving consecutive wet weeks in Akkarayan Kulam (DL1f) is very low during the latter part of the year.

\section{Conclusions}

The AERs in the Dry zone are vulnerable to droughts especially during March to August. However, if cultural operations are carried out in a timely manner the repercussions of dry spells can be minimized to a considerable extent. Holing operation which requires a moist soil is best be done during $38^{\text {th }}$ or $39^{\text {th }}$ standard weeks $\left(17^{\text {th }}\right.$ September to $30^{\text {th }}$ September). Planting of rubber should coincide with $43^{\text {rd }}$ and $44^{\text {th }}$ weeks $\left(22^{\text {nd }}\right.$ October to $04^{\text {th }}$ November) to catch the maximum possible length of the wet season to assure optimal establishment success. First, second and third fertilizer applications in the first year of planting need to be done respectively, during $51^{\text {st }} / 52^{\text {nd }}\left(17^{\text {th }}\right.$ to $31^{\text {st }}$ December), $13^{\text {th }} / 14^{\text {th }}$ weeks $\left(26^{\text {th }}\right.$ March to $8^{\text {th }}$ April $)$ and $39^{\text {th }} / 40^{\text {th }}$ weeks $\left(24^{\text {th }}\right.$ September to $7^{\text {th }}$ October) to avoid heavy rains and dry spells. All these dates have been computed using the probability theory in various ways. Hence, it should be noted that it is impossible to prevent any departures from these stipulated dates. Yet, through proper cultural operations and moisture management practices in rubber plantations, viz., irrigation, mulching and intercropping throughout the immature phase of rubber, one can assure a healthy rubber plantation with minimum vacancies to reach the tappable status.

\section{Acknowledgements}

The work connected with this article was carried out under the project 
"Empowering rubber farmers in nontraditional rubber growing areas through knowledge on combating adverse impacts of environment for better productivity" funded by National Research Council (NRC) grant No. 11125. The authors are grateful to NRC for the financial assistance.

\section{References}

Chithranayana, R D and Punyawardene, B V R (2008). Identification of drought prone agro-ecological regions in Sri Lanka. Journal of the National Science Foundation of Sri Lanka 36(2), 117123.

Gabriel, K R and Neumann, J (1962). A Markov chain model for daily rainfall occurrence at Tel Aviv. Quarterly Journal of the Royal Meteorological Society 88, 90-95.

Liyanage, A de S, Gibbs, Ann and Weerasinghe, A R (1984). A cropweather calendar for rubber. Proceedings International Rubber Conference, Colombo, Sri Lanka.

Punyawardene, B V R (1998). Assessment of growing seasons characteristics in the Dry zone of Sri Lanka based on stochastic simulation of rainfall and soil water status. A thesis submitted in partial fulfillment of the requirements for the degree of Doctor of Philosophy, Lincoln University, UK.

Rodrigo, $\mathrm{V} \mathrm{H}$ L, Iqbal, S M M and Munasinghe, E S (2009). Rural livelihood and rubber cultivation in eastern province of Sri Lanka. Journal of the Rubber Research Institute of Sri Lanka 89, 58-69.

Wijesuriya, W and Herath, H M L K (2001). Effects of climate change on rubber plantation in Sri Lanka A report submitted to the Center for Climate Change Studies of the Department of Meteorology, Sri Lanka.

Wijesuriya, Wasana, Herath, Keminda and Karunaratne, Senani (2010). Use of rainfall patterns for efficient operation of agronomic practices in rubber plantations: The case of Moneragala district. Bulletin of the Rubber Research Institute of Sri Lanka 51, 7080.

Wijesuriya, Wasana, Herath, Keminda and Abeywardene, Vidura (2005). Characteristics of rainfall in the Moneragala district. Bulletin of the Rubber Research Institute of Sri Lanka, 46, 1-9.

Yogaratnam, N (2001). Land suitability evaluation, selection and soil conservation. In: Hand Book of Rubber, Volume 1 (Agronomy), (Eds. L.M.K. Tillekeratne and A. Nugawela), Rubber Research Institute of Sri Lanka, Agalawatta, Sri Lanka.

Address for correspondence: Dr (Mrs) Wasana Wijesuriya, Biometrician, Rubber Research Institute of Sri Lanka, Dartonfield, Agalawatta, Sri Lanka.

e-mail: wasanaw@sltnet.lk. 